\title{
ATP released from $\beta$-amyloid-stimulated microglia induces reactive oxygen species production in an autocrine fashion
}

\author{
Soo Yoon Kim ${ }^{1,2}$, Ju Hyun Moon ${ }^{1,2}$, Hwan Goo Lee ${ }^{1,2}$, \\ Seung Up Kim ${ }^{3,4}$ and Yong Beom Lee $e^{1,2,3,5}$ \\ ${ }^{1}$ Neuroscience Graduate Program \\ ${ }^{2}$ Division of Cell Transformation and Restoration \\ ${ }^{3}$ Brain Disease Research Center \\ Ajou University School of Medicine \\ Suwon 443-721, Korea \\ ${ }^{4}$ Division of Neurology, Department of Medicine \\ University of British Columbia \\ Vancouver, British Columbia, Canada V6T $1 Z 3$ \\ ${ }^{5}$ Corresponding author: Tel, 82-31-219-4558; \\ Fax, 82-31-216-6381; E-mail, yblee@ ajou.ac.kr
}

Accepted 19 November 2007

Abbreviations: $A \beta, \beta$-amyloid peptide; $A D$, Alzheimer's disease; DCF-DA, dihydrodichlorofluorescein diacetate; $f A \beta$, fibrillar $A \beta ; \mathrm{O}_{2}^{-}$, superoxide anion; oATP, oxidized ATP; $\mathrm{P} 2 \mathrm{X}_{7} \mathrm{R}, \mathrm{P} 2 \mathrm{X}_{7}$ receptor; ROS, reactive oxygen species

\begin{abstract}
Present study demonstrated that fibrillar $\beta$-amyloid peptide $\left(\mathrm{fA} \beta_{1-42}\right)$ induced ATP release, which in turn activated NADPH oxidase via the $\mathrm{P}_{2} \mathrm{X}_{7}$ receptor $\left(\mathrm{P}^{2} \mathrm{X}_{7} \mathrm{R}\right)$. Reactive oxygen species (ROS) production in $\mathrm{fA} \beta_{1-42^{-}}$ treated microglia appeared to require $\mathrm{Ca}^{2+}$ influx from extracellular sources, because ROS generation was abolished to control levels in the absence of extracellular $\mathrm{Ca}^{2+}$. Considering previous observation of superoxide generation by $\mathrm{Ca}^{2+}$ influx through $\mathrm{P}_{2} \mathrm{X}_{7} \mathrm{R}$ in microglia, we hypothesized that ROS production in fA $\beta$-stimulated microglia might be mediated by ATP released from the microglia. We therefore examined whether $f A \beta_{1-42}$-induced $\mathrm{Ca}^{2+}$ influx was mediated through $\mathrm{P}_{2} \mathrm{X}_{7} \mathrm{R}$ activation. In serial experiments, we found that microglial pretreatment with the $P 2 X_{7} R$ antagonists Pyridoxal-phosphate-6-azophenyl-2',4'- disulfonate $(100 \mu \mathrm{M})$ or oxidized ATP $(100 \mu \mathrm{M})$ inhibited $f A \beta$-induced $\mathrm{Ca}^{2+}$ influx and reduced $R O S$ generation to basal levels. Furthermore, ATP efflux from $f A \beta_{1-42^{-}}$ stimulated microglia was observed, and apyrase treatment decreased the generation of ROS. These findings provide conclusive evidence that $\mathrm{fA} \beta$-stimulated ROS generation in microglial cells is regulated by ATP released from the microglia in an autocrine manner.
\end{abstract}

Keywords: adenosine triphosphate; Alzheimer's disease; amyloid $\beta$-protein; calcium; microglia; NADPH oxidase; purinoceptor $\mathrm{P} 2 \mathrm{Z}$; reactive oxygen species

\section{Introduction}

A neuropathological characteristic of Alzheimer's disease $(A D)$ is the appearance of neuritic plaques consisting of extracellular beta-amyloid peptide $(A \beta)$ surrounded by reactive microglial cells (Sastre et al., 2006). It has been suggested that fibrillar $A \beta$ $(\mathrm{fA} \beta)$ stimulates reactive oxygen species (ROS) production from cultured microglial cells via activation of NADPH oxidase (Bianca et al., 1999). In addition, $f A \beta$ mediated neurotoxicity in mixed neuron-microglia cultures by causing the production of ROS (Qin et al., 2002). Furthermore, NADPH oxidase activation has been identified in $A D$ brains (Shimohama et al., 2000). These findings suggest that microglia-mediated oxidative stress, via NADPH oxidase activation, plays a critical role in the pathogenesis of $A D$.

NADPH oxidase is a multicomponent enzyme that is composed of the cytosolic components, $\mathrm{p} 40^{\text {phox }}, \mathrm{p} 47^{\text {phox }}, \mathrm{p} 67^{\text {phox }}$ and the small G-protein Rac, and the plasma membrane components p22 ${ }^{\text {phox }}$ and gp91 ${ }^{\text {phox }}$ (Lambeth, 2004). Activation of NADPH oxidase occurs when inflammatory stimuli bring about the phosphorylation of $\mathrm{p} 47^{\text {phox }}$ and p $67^{\text {phox }}$, and GDP/GTP exchange on Rac, causing these proteins to translocate to the membrane, where they assemble with $\mathrm{p} 22^{\text {phox }}$ and $\mathrm{gp} 91^{\text {phox }}$ (DeLeo and Quinn, 1996). The translocation of both the $\mathrm{p} 47^{\text {phox }}$ and $\mathrm{p} 67^{\text {phox }}$ subunits from the cytosol to the membrane has been observed in $A D$ brain and $f A \beta$-stimulated microglial cells (Bianca et al., 1999; Shimohama et al., 2000). However, the mechanisms responsible for this $f A \beta$-stimulated NADPH oxidase activation remain largely unknown.

ATP is known to be released by neurons and glia under conditions such as trauma, ischemia/ hypoxia, and inflammation, and such release is a potential cause of neurodegeneration (Burnstock, 2007). Extracellular ATP has been reported to stimulate ROS production via P2 purinergic receptors in eosinophils and microglia (Dichmann et al., 2000; Parvathenani et al., 2003). In eosinophils, elevation of intracellular calcium concentra- 
tion $\left(\left[\mathrm{Ca}^{2+}\right]_{i}\right)$ plays a crucial role in the regulation of ROS production (Dichmann et al., 2000). In microglia $\left[\mathrm{Ca}^{2+}\right]_{\mathrm{i}}$ increases caused by the stimulation of the $P 2 X_{7}$ receptor $\left(P 2 X_{7} R\right)$ induces NADPH oxidase-mediated superoxide generation (Parvathenani et al., 2003). More importantly, upregulated expression of $P 2 X_{7} R$ in $A D$ brain and $f A \beta$-treated microglial cells has been recently reported (McLarnon et al., 2006).

Taking these data together, we hypothesized that ROS production in $f A \beta$-stimulated microglia might be mediated by ATP released from the microglia. To explore this hypothesis further, we determined whether $f A \beta$-stimulated microglia release ATP, which could then modulate $\left[\mathrm{Ca}^{2+}\right]_{\mathrm{i}}$ elevation via $\mathrm{P} 2 \mathrm{X}_{7} \mathrm{R}$, resulting in ROS production.

\section{Materials and Methods}

\section{Reagents}

An $A \beta$ peptide corresponding to human $A \beta$ amino acids 1-42 $\left(A \beta_{1-42}\right)$ was purchased from the American Peptide Company (Sunnyvale, CA). Pyridoxal-phosphate-6-azophenyl-2',4'-disulfonate (PPADS), adenosine 5'-triphosphate 2', 3'-acylic dialcohol (oxidized ATP; oATP), apyrase (an ATP-hydrolyzing enzyme), 2',7'-dihydrodichlorofluorescein diacetate (DCF-DA), pluronic F-127, DNase I, an ATP bioluminescence assay kit, and a protease inhibitor mixture, were all purchased from Sigma (St. Louis, MO). The Amplex Red hydrogen peroxide/peroxidase assay kit and the $\mathrm{Ca}^{2+}$ indicator Fluo-3/AM were from Molecular Probes (Eugene, $\mathrm{OR})$.

\section{Microglial cell culture}

Microglial cultures were prepared from the brains of 3-day-old Sprague-Dawley rats as described previously (Kim et al., 2002). Briefly, whole brains were dissected into small cubes, incubated in D-PBS (JBI, Taegu, Korea) containing $0.1 \%$ trypsin and $40 \mu \mathrm{g} / \mathrm{ml}$ DNase I for $15 \mathrm{~min}$ at $37^{\circ} \mathrm{C}$, and dissociated into single cells by gentle pipetting. Dissociated cells were suspended in DMEM (JBI) containing $5 \%$ horse serum, $5 \mathrm{mg} / \mathrm{ml}$ glucose, 100 $\mathrm{U} / \mathrm{ml}$ penicillin and $100 \mu \mathrm{g} / \mathrm{ml}$ streptomycin, and plated on poly-D-lysine-coated T-75 culture flasks, and incubated at $37^{\circ} \mathrm{C}$ in incubator with $5 \% \mathrm{CO}_{2} /$ $95 \%$ air atmosphere. After 2-4 weeks of growth in flasks, microglia floating in the medium were collected and grown in separate 96-well plates or on coverslips.

\section{Detection of ROS}

(1) Measurement of extracellular ROS: Microglial cells were plated at approximately $1 \times 10^{5}$ cells/well in 96-well plates, and then stimulated with $f A \beta_{1-42}$. For preparing $f A \beta$, the lyophilized $A \beta_{1-42}$ peptides were dissolved in sterile 10\% DMSO in PBS at a concentration of $350 \mu \mathrm{M}$ and aged $5-7 \mathrm{~d}$ at $37^{\circ} \mathrm{C}$, and then diluted in a culture medium for use in the experiments. After $f A \beta_{1-42}$ treatment, $100 \mu \mathrm{l}$ of supernatant were transferred to microplate and mixed with $100 \mu$ I DMEM without phenol red but containing of $0.5 \mu \mathrm{M}$ Amplex Red, and $1 \mathrm{U} / \mathrm{ml}$ HRP (Amplex Red hydrogen peroxide/peroxidase assay kit). The Amplex Red reagent reacts with $\mathrm{H}_{2} \mathrm{O}_{2}$ in the presence of HRP to produce the fluorescent compound resorufin (Zhou et al., 1997). Fluorescence intensities were measured at indicated times using a LS-55 luminescence spectrophotometer (Perkin Elmer Instruments, Wellesley, MA).

(2) Measurement of intracellular ROS: Intracellular ROS levels were measured using the fluorescent dye DCF-DA, which is readily converted to a fluorescent product in the presence of ROS in cells. In brief, cells were preincubated with PPADS $(10,100 \mu \mathrm{M})$, oATP $(10,100 \mu \mathrm{M}), 500 \mu \mathrm{M}$ EGTA, or $5 \mathrm{U}$ of apyrase, and then treated with $0.5 \mu \mathrm{M}$ $f A \beta_{1-42}$. $A A \beta_{1-42}$-stimulated cells were incubated with $10 \mu \mathrm{M}$ DCF-DA in HBSS $(145 \mathrm{mM} \mathrm{NaCl}, 2.5 \mathrm{mM}$ $\mathrm{KCl}, 1.8 \mathrm{mM} \mathrm{MgCl}, 1 \mathrm{mM} \mathrm{CaCl} 2,10 \mathrm{mM}$ Dglucose and $20 \mathrm{mM}$ HEPES; $\mathrm{pH}$ 7.4) for $30 \mathrm{~min}$. The cells were then washed extensively with D-PBS to remove extracellular DCF-DA, and fluorescence images were taken using an IX71 confocal laser scanning microscope (Olympus; Tokyo, Japan).

\section{$\mathrm{Ca}^{2+}$ imaging}

Intracellular $\mathrm{Ca}^{2+}$ concentration was monitored by loading cells with the fluorescent $\mathrm{Ca}^{2+}$ indicator Fluo-3/AM, convertible to Fluo-3 in the presence of $\mathrm{Ca}^{2+}$. Cultured microglia plated onto poly-D-lysinecoated $25 \mathrm{~mm}$ glass coverslips were incubated with $2 \mu \mathrm{M}$ of the acetoxymethyl ester of Fluo-3 (Fluo-3/AM) and $0.02 \%$ pluronic F-127 in HBSS for $30 \mathrm{~min}$ at $37^{\circ} \mathrm{C}$, and then washed with HBSS. Fluo-3-loaded cells were placed in a perfusion chamber mounted on the stage of a confocal laser-scanning microscope and stimulated with 0.5 $\mu \mathrm{M} f A \beta_{1-42}$. To measure the intracellular calcium concentration, a confocal laser-scanning microscope (IX71, Olympus) equipped with an Argon/ Keron laser (15 mW; Coherent, Santa Clara, CA) was used. Fluo-3 was excited by the $488 \mathrm{~nm}$ line of an argon laser and the fluorescence was measured at an emission wavelength above $510 \mathrm{~nm}$. 


\section{Western blot analysis}

Microglial cells treated with $f A \beta_{1-42}$ were lysed with lysis buffer $\left(10 \mathrm{mM} \mathrm{Na}_{2} \mathrm{HPO}_{4}, 150 \mathrm{mM} \mathrm{NaCl}, 0.5 \%\right.$ sodium deoxycholate, $0.1 \%$ SDS, and $1 \%$ NP 40 ; $\mathrm{pH}$ 7.5). Lysates were centrifuged at $13,000 \times g$ for $10 \mathrm{~min}$ at $4^{\circ} \mathrm{C}$ and supernatants were collected. An aliquot of each sample containing $20 \mu \mathrm{g}$ total protein was loaded onto a $10 \%$ acrylamide gel, and then transferred to a PVDF membrane. The blots were incubated with blocking buffer $[0.5 \%$ skim milk in TBST $(20 \mathrm{mM}$ Tris- $\mathrm{HCl}, 500 \mathrm{mM} \mathrm{NaCl}$, $0.05 \%$ Tween 20, $\mathrm{pH} 7.5$ )] at room temperature for $1 \mathrm{~h}$, and incubated with primary monoclonal antibodies against the $p 67^{\text {phox }}(1: 500$; BD Biosciences, San Diego, CA), and HRP conjugated anti-mouse secondary antibody $(1: 1,000$; Amersham Pharmacia).

\section{Cell fractionation}

Microglial cells were harvested and resuspended in a cold hypotonic solution ( $0.25 \mathrm{M}$ sucrose, 10 $\mathrm{mM}$ Tris- $\mathrm{HCl}$, and $5 \mathrm{mM} \mathrm{MgCl} 2 ; \mathrm{pH} 7.4$ ) including a protease inhibitor mixture, and centrifuged at $600 \times$ $g$ for $10 \mathrm{~min}$. The supernatant was ultracentrifuged at $100,000 \times g$ for $1.5 \mathrm{~h}$ at $4^{\circ} \mathrm{C}$. The resulting supernatant was removed and saved as the cytosolic fraction, and the membrane pellet was resuspended in hypotonic solution containing $1 \%$ Triton X-100. Samples were analyzed by Western blotting using antibodies against the NADPH oxidase components, as described above.

\section{ATP efflux measurement}

To examine whether extracellular ATP was released from microglial cells by $f A \beta_{1-42}$ treatment, cells $\left(3 \times 10^{4}\right.$ cells/well) were plated in 96-well plates, and treated with $0.5 \mu \mathrm{M} f \beta_{1-42}$ for various times. After incubation, supernatant fluids of individual wells were transferred into sterile tubes and heated at $95^{\circ} \mathrm{C}$ for $2 \mathrm{~min}$. Extracellular ATP in supernatants was immediately measured using the luciferase-luciferin assay of the ATP bioluminescence assay kit following the instructions of the manufacturer using a luminometer (TD2020; Turner Designs, Sunnyvale, CA).

\section{Statistical analysis}

All statistical comparisons in this study were performed using one-way ANOVA with the TukeyKramer multiple comparisons test, and data are expressed as mean \pm SEM. A value of $P<0.05$ was considered statistically significant.

\section{Results}

\section{$f A \beta_{1-42}$ induces sustained ROS production in microglia}

Figure $1 \mathrm{~A}$ shows that minimum concentration of

A

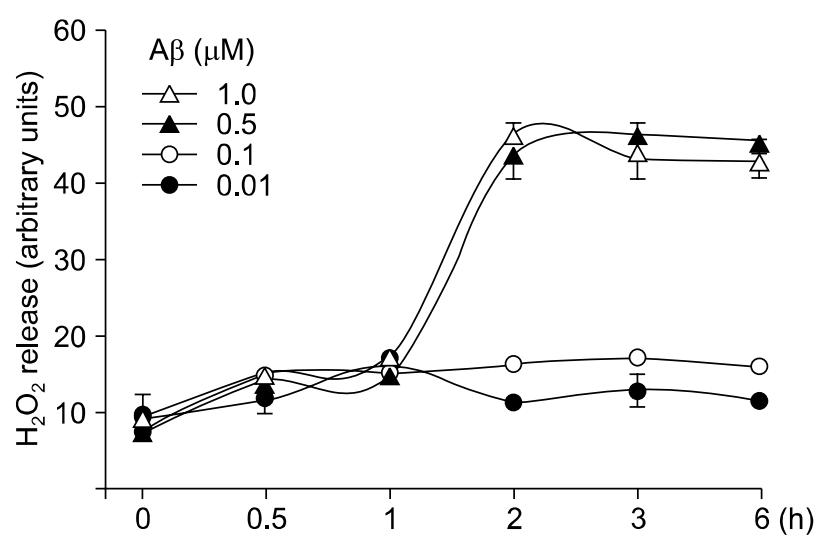

B

$0 \min$

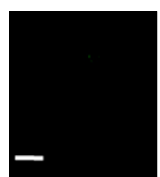

$10 \mathrm{~min}$

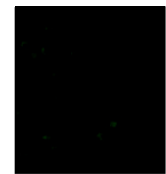

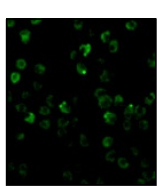

$1 \mathrm{~h}$

$2 \mathrm{~h}$

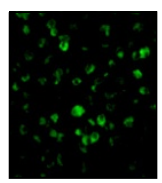

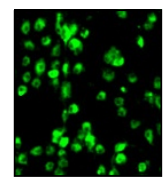

$3 \mathrm{~h}$

$6 \mathrm{~h}$

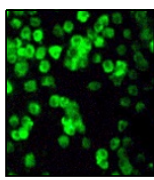

Figure 1. Dose-response and time-response of $f A \beta_{1-42}$-induced ROS production in microglia. Primary rat microglia were plated in 96-well plates $(1 \times$ $10^{5}$ cells/well $)$ or onto coverslips $\left(3 \times 10^{4}\right.$ cells/coverslip). (A) $\mathrm{H}_{2} \mathrm{O}_{2}$ production in microglia stimulated with various concentrations of $f A \beta_{1-42}$ was determined over $6 \mathrm{~h}$. The amounts of $\mathrm{H}_{2} \mathrm{O}_{2}$ released into media were measured using Amplex Red. (B) Intracellular ROS levels were assayed using $10 \mu \mathrm{M}$ DCF as described in Materials and Methods. Fluorescence (DCF) images were taken using an IX71 confocal microscope (Olympus). Scale bar, $100 \mu \mathrm{m}$ 
$f A \beta_{1-42}$ required for ROS production in microglia is $0.5 \mu \mathrm{M}$. Release of $\mathrm{H}_{2} \mathrm{O}_{2}$ commenced at $1 \mathrm{~h}$, peaked at $2 \mathrm{~h}$ after $\mathrm{fA} \beta_{1-42}$ treatment, and then continued for $6 \mathrm{~h}$. Next, we evaluated intracellular ROS levels in microglia stimulated with $0.5 \mu \mathrm{M}$ $\mathrm{fA} \beta_{1-42}$ by measuring fluorescence signals from DCF-DA. The DCF fluorescence signals also significantly increased in the interval 0.5-6 $\mathrm{h}$ after $\mathrm{fA} \beta_{1-42}$ treatment (Figure 1B). These results indicate that ROS production in $f A \beta_{1-42}$-stimulated microglia is initiated slowly, and continues for a long period.

\section{Extracellular $\mathrm{Ca}^{2+}$ is required for $\mathrm{fA} \beta_{1-42 \text {-induced } \mathrm{ROS}}$ production in microglia}

Previous studies showed that ROS production in phagocytic cells is mediated by $\left[\mathrm{Ca}^{2+}\right]_{i}$ elevation (Baggiolini et al., 1993; Geiszt et al., 1999). We therefore investigated the effect of extracellular

$\mathbf{A}$

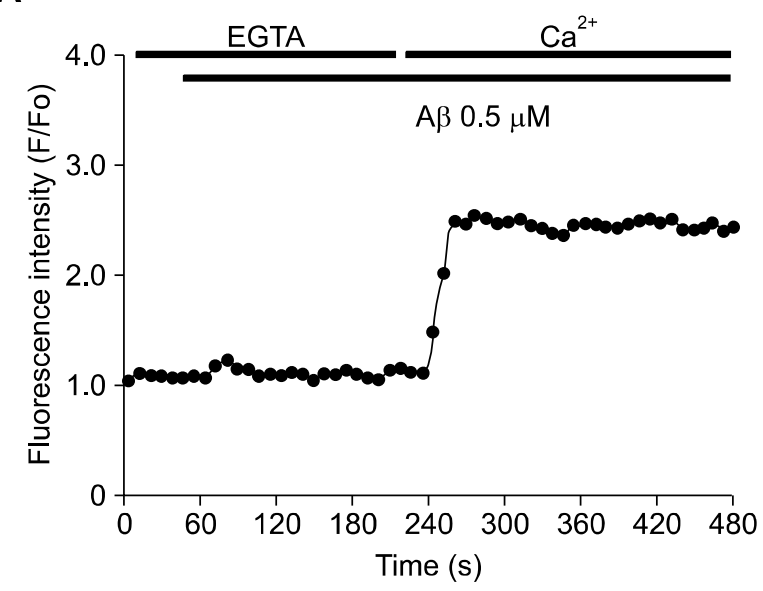

B

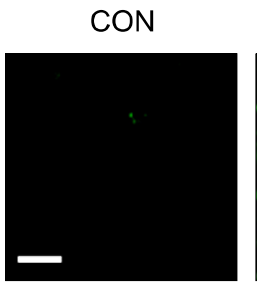

$\mathrm{A} \beta 0.5 \mu \mathrm{M}$

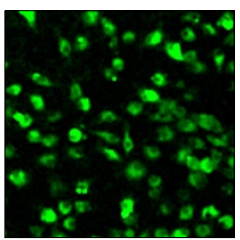

$A \beta+E G T A$

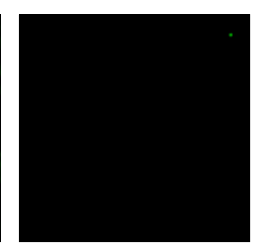

Figure 2. Effects of EGTA on $\left[\mathrm{Ca}^{2+}\right]_{i}$ and ROS production in $\mathrm{fA} \beta_{1-42}$-stimulated microglia. Microglial cells were plated onto glass coverslips $\left(3 \times 10^{4}\right.$ cells/coverslip) in either HBSS or HBSS without $\mathrm{Ca}^{2+}$ containing $0.5 \mathrm{mM}$ EGTA, and then stimulated with $0.5 \mu \mathrm{M}$ fA $\beta_{1-42 .}$. (A) Intracellular $\mathrm{Ca}^{2+}$ concentration was measured by Fluo-3 as described in Materials and Methods, and represented by the ratio between the fluorescence intensity after treatment $(F)$ and fluorescence in the resting state $\left(\mathrm{F}_{0}\right)$. (B) Intracellular ROS levels were assayed using $10 \mu \mathrm{M}$ DCF. Fluorescence (DCF) images were taken using an IX71 confocal microscope (Olympus). Scale bar, $100 \mu \mathrm{m}$.

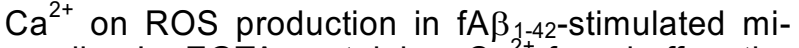
croglia. In EGTA-containing $\mathrm{Ca}^{2+}$-free buffer, the change in $\left[\mathrm{Ca}^{2+}\right]_{i}$ was abolished, whereas $\left[\mathrm{Ca}^{2+}\right]_{i}$ increased when buffer was changed to $\mathrm{Ca}^{2+}$-containing buffer, indicating that $f A \beta_{1-42}$ appeared to stimulate $\mathrm{Ca}^{2+}$ influx only from extracellular sources (Figure 2A). The DCF fluorescence signals showed that $f A \beta_{1-42}$-stimulated ROS production was blocked to control levels when cells were preincubated in EGTA-containing $\mathrm{Ca}^{2+}$-free medium (Figure $2 \mathrm{~B}$ ). These results clearly suggest that $\mathrm{Ca}^{2+}$ influx from the extracellular milieu is necessary for the $f A \beta_{1-42}$-induced ROS production.

\section{fA $\beta_{1-42}$-induced $\mathrm{Ca}^{2+}$ influx and ROS production are mediated by ATP released from microglia through $\mathbf{P} 2 \mathrm{X}_{7} \mathrm{R}$ activation}

Superoxide generation by $\mathrm{Ca}^{2+}$ influx through $\mathrm{P} 2 \mathrm{X}_{7} \mathrm{R}$ was observed in microglia (Parvathenani et al., 2003). Therefore, we examined whether $f A \beta_{1-42-}$ induced $\mathrm{Ca}^{2+}$ influx was mediated through $\mathrm{P} 2 \mathrm{X}_{7} \mathrm{R}$ activation. Apyrase treatment prevented $f A \beta_{1-42-}$ induced $\mathrm{Ca}^{2+}$ influx in a dose dependent manner

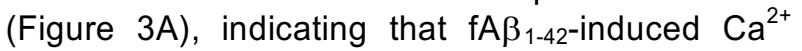
influx is mediated by ATP released from microglia. Pretreatment of microglia with the $P 2 X_{7} R$ antagonists PPADS $(100 \mu \mathrm{M})$ or oATP $(100 \mu \mathrm{M})$ inhibited $f A \beta_{1-42}$-induced $\mathrm{Ca}^{2+}$ influx to baseline levels (Figure 3B). Next, we measured DCF fluorescence signals in microglial cells pretreated with PPADS or OATP. As can be seen in Figure $3 \mathrm{C}$ and $D$, DCF fluorescence signals were significantly suppressed by PPADS and oATP at 10-100 $\mu \mathrm{M}$.

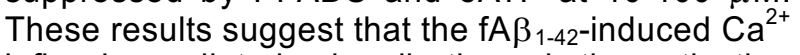
influx is mediated primarily through the activation of the $P 2 X_{7} R$, resulting in ROS generation.

\section{fA $\beta_{1-42}$-induced NADPH oxidase activation is mediated by ATP released from microglia}

We examined the activation of NADPH oxidase by monitoring the membrane translocation of $p 67^{\text {phox }}$ over time. Following $f A \beta_{1-42}$ treatment, the amounts of $p 67^{\text {phox }}$ in the membrane fraction increased up to 90 min post-treatment, and then decreased over the next $6 \mathrm{~h}$ (Figure 4A). In addition, PPADS, oATP, EGTA, and apyrase (an ATP-hydrolyzing enzyme) prevented the $f A \beta_{1-42}$-induced membrane translocation of $\mathrm{p} 67^{\text {phox }}$ (Figure 4B). Translocation of the cytosolic factor $\mathrm{p} 67^{\mathrm{phox}}$ to the plasma membrane started at about 30 min post-stimulation, and was prevented by apyrase treatment. Based on these findings, we wondered whether ATP is released from $f A \beta_{1-42}$-stimulated microglia. The ROS production was abolished by apyrase treatment, but 
A

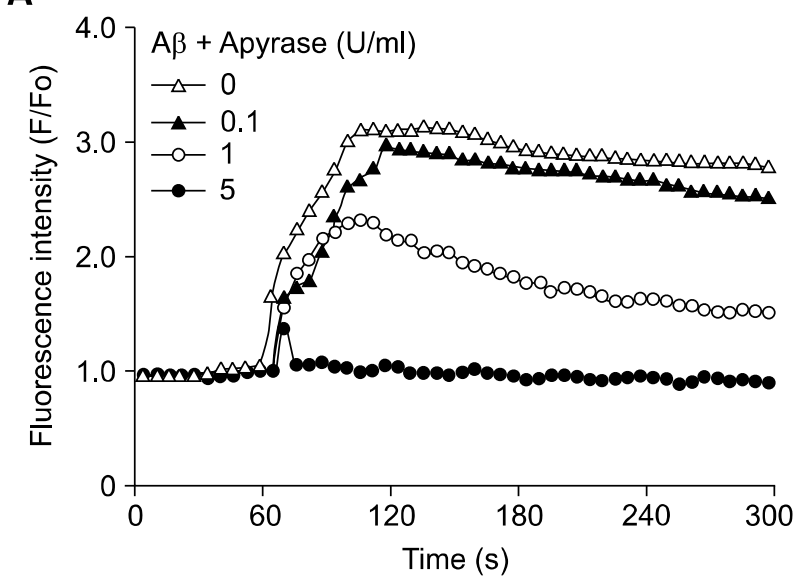

C
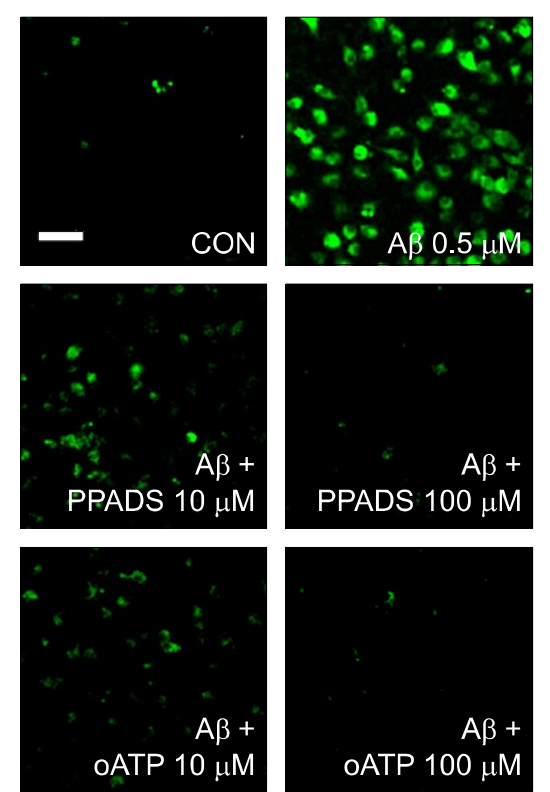

B

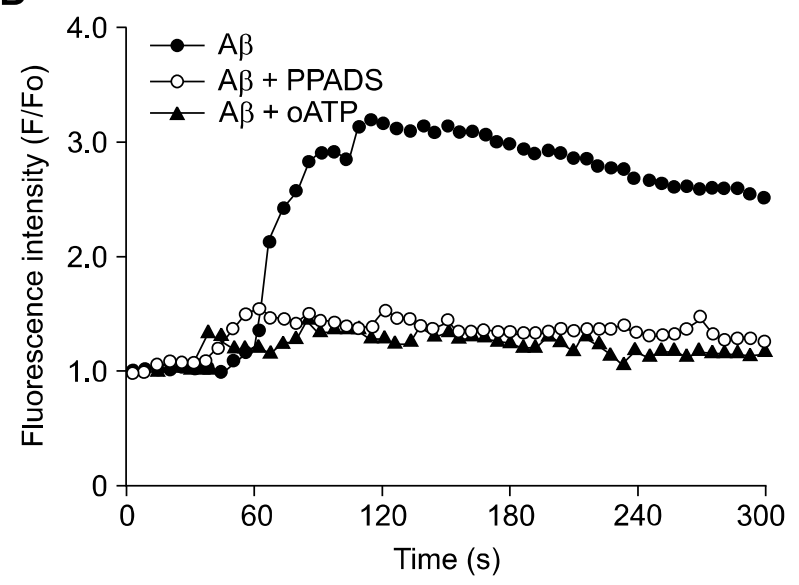

D

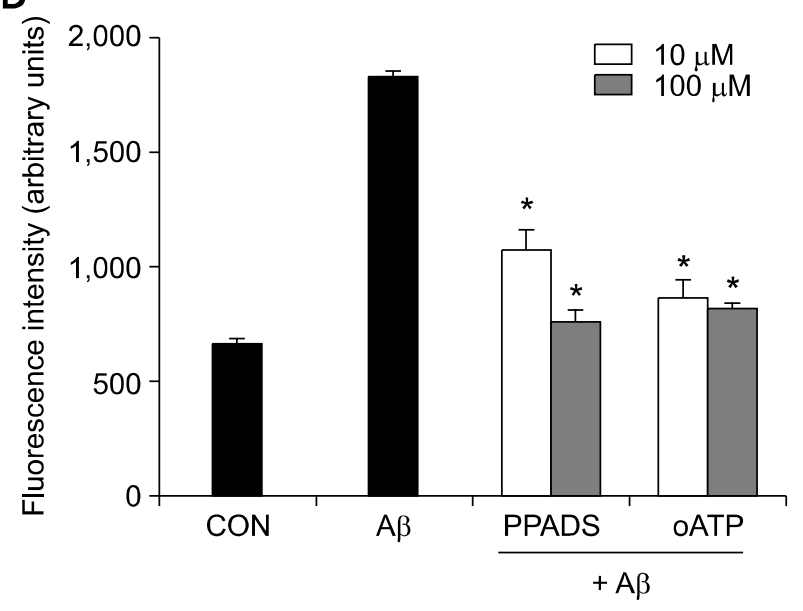

Figure 3. Effects of apyrase or $P 2 X_{7} R$ antagonists on $f A \beta_{1-42}$-induced $\left[\mathrm{Ca}^{2+}\right]_{i}$ changes in microglia. Microglial cells were plated onto coverslips $\left(3 \times 10^{4}\right.$ cells/coverslip), treated with apyrase $(5 \mathrm{U} / \mathrm{ml})$ plus fA $\beta_{1-42}(0.5 \mu \mathrm{M})(\mathrm{A})$, or pretreated with PPADS $(100 \mu \mathrm{M})$ or oATP $(100 \mu \mathrm{M})$ for $1 \mathrm{~h}$, and then treated with $0.5 \mu \mathrm{M} f \beta_{1-42}$ (B and $C$ ). ( $A$ and $B$ ) Intracellular $\mathrm{Ca}^{2+}$ concentration was measured by Fluo-3 as described in Materials and Methods, and represented by the ratio between the fluorescence intensity after treatment $(F)$ and fluorescence in the resting state $\left(F_{0}\right)$. $(C)$ Intracellular ROS levels were assayed using $10 \mu \mathrm{M}$ DCF. Fluorescence (DCF) images were taken using an IX71 confocal microscope (Olympus). Scale bar, $100 \mu \mathrm{m}$. (D) DCF intensities of cells in (C) were counted using Image Gauge 4.0 (Fujifilm). Values are mean \pm SEM of $40-50$ cells. ${ }^{*} P<0.001$ compared with $f A \beta 1-42$.

was not affected by boiled apyrase (Figure $4 \mathrm{C}$ and $D)$, suggesting that ATP released from $A \beta_{1-42-}$ stimulated microglia might trigger ROS production. We also found that the amount of extracellular ATP reached a maximum level $1 \mathrm{~h}$ after stimulation with $\mathrm{fA} \beta_{1-42}$, and this level was sustained for $6 \mathrm{~h}$ (Figure $4 \mathrm{E})$. These results suggest that $f A \beta_{1-42}$-induced $\mathrm{P} 2 \mathrm{X}_{7} \mathrm{R}$ activation may be regulated by ATP released from microglia in an autocrine manner.

\section{Discussion}

The major new finding in this study is that $f A \beta_{1-42}$ induces ATP release from microglia and that ATP regulates ROS generation through the activation of $\mathrm{P} 2 \mathrm{X}_{7} \mathrm{R}$ and $\mathrm{Ca}^{2+}$ influx. It is believed that phagocytes including neutrophils and macrophages produce ROS to counter invading pathogens, in a phenomenon known as the respiratory burst. An excess of the superoxide anion $\left(\mathrm{O}_{2}^{-}\right)$can, however, cause serious damage to the host. The phagocyte 
A

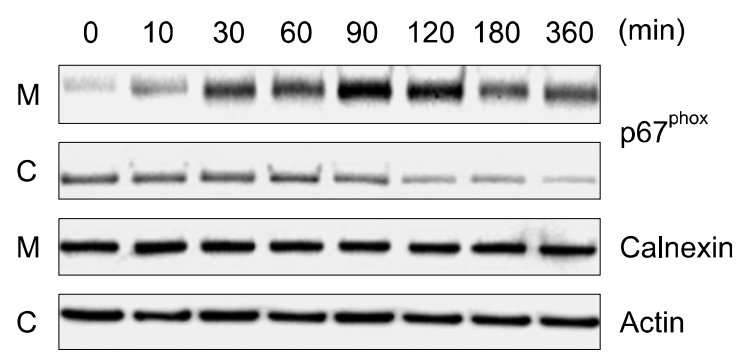

B

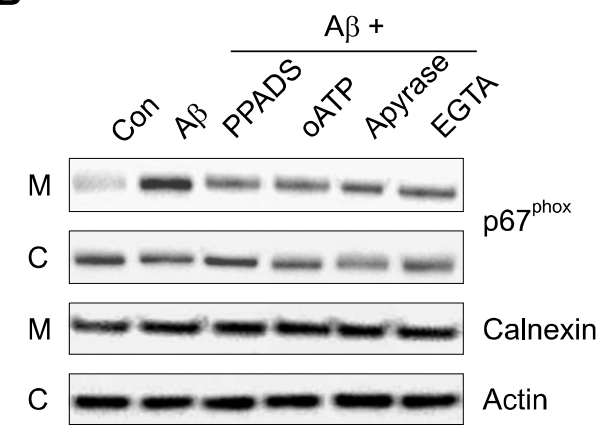

C

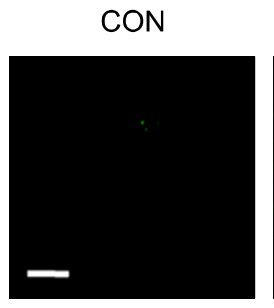

$\mathrm{A} \beta 0.5 \mu \mathrm{M}$

$A \beta+$ Apyrase

A $\beta+$ Boiled Apyrase
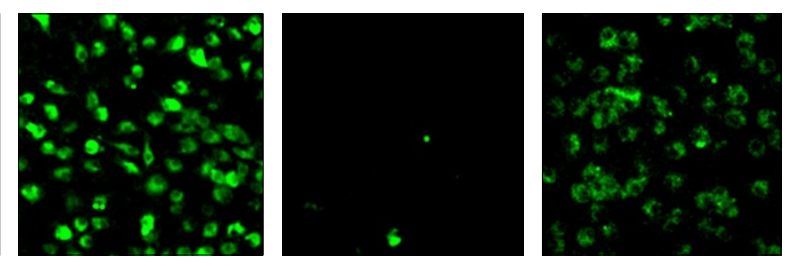

D

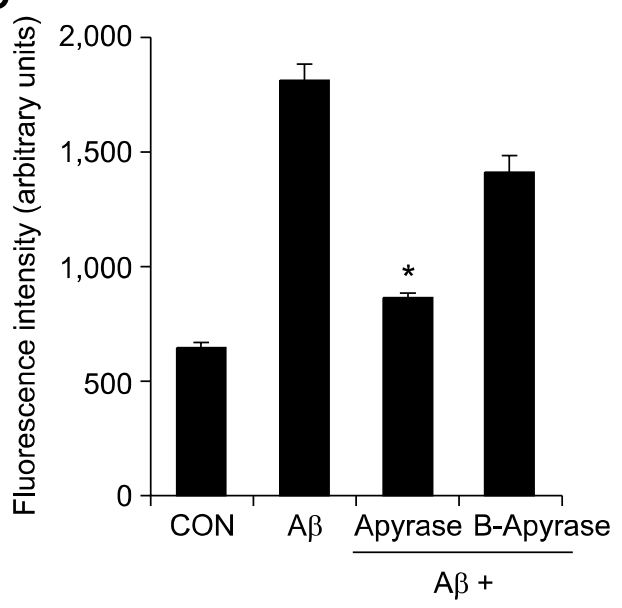

E

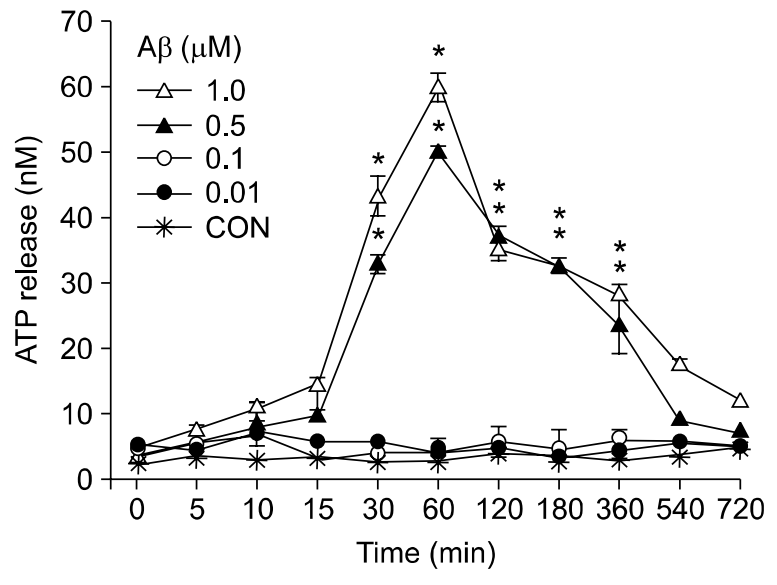

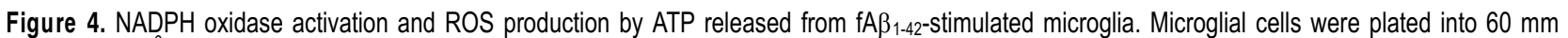
dishes $\left(2 \times 10^{6}\right.$ cells), and treated with $0.5 \mu \mathrm{M} \mathrm{fA \beta} \beta_{1-22}$ for the time periods indicated (A), or pretreated with $100 \mu \mathrm{M}$ PPADS, $100 \mu \mathrm{M} \mathrm{oATP,} 5 \mathrm{U}$ of apyrase, or $0.5 \mathrm{mM} E G T A$, and then treated with $0.5 \mu \mathrm{M} \mathrm{fA \beta} \beta_{1-42}$ for $90 \mathrm{~min}$ (B). (A and B) Lysates were fractionated, and $\mathrm{p} 67^{\text {phox }}$ distributions in cytosolic and membrane fractions were analyzed by Western blot analysis. The cytosol protein actin and the membrane protein calnexin were used as internal standards to normalize experimental data. C, cytosolic fraction; M, membrane fraction. (C) Microglial cells $\left(3 \times 10^{4}\right.$ cells/coverslip) were plated onto coverslips, and treated with $5 \mathrm{U} / \mathrm{ml}$ of apyrase and $0.5 \mu \mathrm{M} f A \beta_{1-42}$ for $2 \mathrm{~h}$. The effect of apyrase on the production of intracellular ROS was measured by DCF fluorescence. Scale bar, $100 \mu \mathrm{m}$. (D) DCF intensities of cells in (C) were measured using Image Gauge 4.0 (Fujifilm). Values are mean \pm SEM of 40-50 cells. ${ }^{*} P<0.001$ compared with $\mathrm{AA} \beta_{1-42}$. (E) Time courses of ATP release into the culture supernatants of $\mathrm{fA} \beta_{1-42}$-stimulated microglia. Microglial cells 3 $\times 10^{4}$ cells/well) were plated into 96 -well plates. ATP concentrations in the culture supernatants were determined at the indicated time points after fA $\beta_{1-42}$ stimulation. Values are mean \pm SEM of triplicate samples. ${ }^{*} P<0.001$ compared with the control.

NADPH oxidase is a major enzyme catalyzing the non-mitochondrial production of $\mathrm{O}_{2}^{-}$(Lambeth, 2004). The activation of NADPH oxidase must therefore be tightly controlled. For example, the bacterial chemoattractant fMet-Leu-Phe (fMLF)mediated $\mathrm{O}_{2}^{-}$production in human polymorpho- nuclear leukocytes peaked at $45 \mathrm{~s}$, and then declined rapidly to $50 \%$ of maximal by 2 min (McPhail and Snyderman, 1983). In contrast, ROS production in our experiments was initiated slowly and continued for a long period. This implied that $f A \beta_{1-42}$-stimulated ROS production in microglia 
employed a process different from the mechanisms used for transient ROS generation in phagocytic cells.

The best-characterized signaling pathway for ROS production in neutrophils is NADPH oxidase activation resulting from elevation in $\left[\mathrm{Ca}^{2+}\right]_{i}$ through a process termed store-operated $\mathrm{Ca}^{2+}$ influx (Thelen et al., 1993). The fMLF-induced activation of the G-protein-coupled formyl peptide receptor triggers $\mathrm{Ca}^{2+}$ release from intracellular stores, followed by an influx of $\mathrm{Ca}^{2+}$ through the plasma membrane (Granfeldt et al., 2002). In contrast, our experiments showed that $f A \beta_{1-42}$ stimulation provoked $\mathrm{Ca}^{2+}$ influx but not $\mathrm{Ca}^{2+}$ release from intracellular stores, and that ROS production was decreased to control levels by blocking $\mathrm{Ca}^{2+}$ influx. These differences in methods of $\left[\mathrm{Ca}^{2+}\right]_{i}$ increase may be correlated with the sustained production of ROS in our experiment compared with transient ROS generation in phagocytic cells. In fact, a recent study showed that BzATP, a P2X $\mathrm{X}_{7}$ R-specific agonist, caused $\mathrm{Ca}^{2+}$ influx from extracellular sources only (Parvathenani et al., 2003). We therefore examined the possible involvement of $P 2 X_{7} R$ in $f A \beta_{1-42}$-mediated $\left[\mathrm{Ca}^{2+}\right]_{i}$ changes and ROS generation, and found that $f A \beta_{1-42}$-induced ROS generation in microglia was entirely attributable to the activation of $P 2 X_{7} R$. A recent study also reported that $P 2 X_{7} R$ expression was upregulated in primary microglia obtained from an AD brain, and that ATP abnormally triggered the $\mathrm{Ca}^{2+}$ response (McLarnon et al., 2005).

A putative mechanism explaining $P 2 X_{7} R-$ dependent ROS generation in $f A \beta_{1-42}$-stimulated microglia is that $f A \beta_{1-42}$ stimulates the secretion of ATP from microglial cells, and that the released ATP subsequently stimulates $P 2 X_{7} R$ activity. In support of this hypothesis, our results showed that both the translocation of $\mathrm{p} 67^{\text {phox }}$ and ROS production were prevented by EGTA, PPADS, OATP, or apyrase treatment. Furthermore, ATP release from $f A \beta_{1-42}$-stimulated microglia was confirmed. Notably, the time course of ATP release agreed with the kinetics of $p 67^{\text {phox }}$ translocation and ROS production, providing conclusive evidence that fA $\beta_{1-42}$-stimulated NADPH oxidase activation in microglial cells is regulated by ATP released from microglia. Recently, it has been recognized that ATP can be released from LPS-stimulated microglial cells (Ferrari et al., 1997; Seo et al., 2004), and a recent study reported that ATP release from glutamate-stimulated microglia was mediated by intracellular $\mathrm{Ca}^{2+}$ release (Liu et al., 2006). Our data show $\mathrm{Ca}^{2+}$ influx from extracellular sources only, implying that $f A \beta_{1-42}$-stimulated ATP release from microglia occurs by a mechanism distinct from that involved in glutamate-stimulated ATP release. Future work on identifying the mechanisms involved in $f A \beta$-stimulated ATP release from microglia will provide a better understanding of the role of microglia in pathological conditions of $A D$.

In conclusion, our study describes a novel mechanism of ROS production by microglia in $A D$ by demonstrating that $f A \beta_{1-42}$ indirectly stimulates NADPH oxidase activation in microglia through ATP release and subsequent activation of $P 2 X_{7} R$.

\section{Acknowledgments}

This work was supported by the Korea Science and Engineering Foundation (KOSEF) through the Brain Disease Research Center at Ajou University.

\section{References}

Baggiolini M, Boulay F, Badwey JA, Curnutte JT. Activation of neutrophil leukocytes: chemoattractant receptors and respiratory burst. FASEB J 1993;7:1004-10

Bianca VD, Dusi S, Bianchini E, Dal Pra I, Rossi F. $\beta$-amyloid activates the $\mathrm{O}_{2}$. forming NADPH oxidase in microglia, monocytes, and neutrophils. A possible inflammatory mechanism of neuronal damage in Alzheimer's disease. J Biol Chem 1999;274:15493-9

Burnstock G. Physiology and pathophysiology of purinergic neurotransmission. Physiol Rev 2007;87:659-797

DeLeo FR, Quinn MT. Assembly of the phagocyte NADPH oxidase: molecular interaction of oxidase proteins. J Leukoc Biol 1996;60:677-91

Dichmann S, Idzko M, Zimpfer U, Hofmann C, Ferrari D, Luttmann W, Virchow C Jr, Di Virgilio F, Norgauer J. Adenosine triphosphate-induced oxygen radical production and CD11b up-regulation: $\mathrm{Ca}^{++}$mobilization and actin reorganization in human eosinophils. Blood 2000;95:973-8

Ferrari D, Chiozzi P, Falzoni S, Hanau S, Di Virgilio F. Purinergic modulation of interleukin- $1 \beta$ release from microglial cells stimulated with bacterial endotoxin. J Exp Med 1997;185: 579-82

Geiszt M, Szeberenyi JB, Kaldi K, Ligeti E. Role of different $\mathrm{Ca}^{2+}$ sources in the superoxide production of human neutrophil granulocytes. Free Radic Biol Med 1999;26: 1092-9

Granfeldt D, Samuelsson M, Karlsson A. Capacitative $\mathrm{Ca}^{2+}$ influx and activation of the neutrophil respiratory burst. Different regulation of plasma membrane- and granulelocalized NADPH-oxidase. J Leukoc Biol 2002;71:611-7

Kim KY, Kim MY, Choi HS, Jin BK, Kim SU, Lee YB. Thrombin induces IL-10 production in microglia as a negative feedback regulator of TNF-alpha release. Neuroreport 2002;13:84952

Lambeth JD. NOX enzymes and the biology of reactive oxygen. Nat Rev Immunol 2004;4:181-9 
Liu GJ, Kalous A, Werry EL, Bennett MR. Purine release from spinal cord microglia after elevation of calcium by glutamate. Mol Pharmacol 2006;70:851-9

McLarnon JG, Choi HB, Lue LF, Walker DG, Kim SU. Perturbations in calcium-mediated signal transduction in microglia from Alzheimer's disease patients. J Neurosci Res 2005;81:426-35

McLarnon JG, Ryu JK, Walker DG, Choi HB. Upregulated expression of purinergic $\mathrm{P}_{2} \mathrm{X}_{7}$ receptor in Alzheimer disease and amyloid-beta peptide-treated microglia and in peptideinjected rat hippocampus. J Neuropathol Exp Neurol 2006; 65:1090-7

McPhail LC, Snyderman R. Activation of the respiratory burst enzyme in human polymorphonuclear leukocytes by chemoattractants and other soluble stimuli. Evidence that the same oxidase is activated by different transductional mechanisms. J Clin Invest 1983;72:192-200

Parvathenani LK, Tertyshnikova S, Greco CR, Roberts SB, Robertson B, Posmantur R. P2X7 mediates superoxide production in primary microglia and is up-regulated in a transgenic mouse model of Alzheimer's disease. J Biol Chem 2003;278:13309-17

Qin L, Liu Y, Cooper C, Liu B, Wilson B, Hong JS. Microglia enhance $\beta$-amyloid peptide-induced toxicity in cortical and mesencephalic neurons by producing reactive oxygen species. J Neurochem 2002;83:973-83

Sastre M, Klockgether T, Heneka MT. Contribution of inflammatory processes to Alzheimer's disease: molecular mechanisms. Int J Dev Neurosci 2006;24:167-76

Seo DR, Kim KY, Lee YB. Interleukin-10 expression in lipopolysaccharide-activated microglia is mediated by extracellular ATP in an autocrine fashion. Neuroreport 2004;15: 1157-61

Shimohama S, Tanino H, Kawakami N, Okamura N, Kodama $H$, Yamaguchi T, Hayakawa T, Nunomura A, Chiba S, Perry G. Activation of NADPH oxidase in Alzheimer's disease brains. Biochem Biophys Res Commun 2000;273:5-9

Thelen M, Dewald B, Baggiolini M. Neutrophil signal transduction and activation of the respiratory burst. Physiol Rev 1993;73:797-821

Zhou M, Diwu Z, Panchuk-Voloshina N, Haugland RP. A stable nonfluorescent derivative of resorufin for the fluorometric determination of trace hydrogen peroxide: applications in detecting the activity of phagocyte NADPH oxidase and other oxidases. Anal Biochem 1997;253:162-8 